\title{
PENGARUH MARINASI RIMPANG KENCUR (Kaempferis galangal L) DAN LAMA PENYIMPANAN PADA SUHU DINGIN TERHADAP KUALITAS FISIK DAN TOTAL PLATE COUNT DAGING AYAM PETELUR AFKIR
}

\author{
PRISKAYANI, N. K., I N. S. MIWADA, DAN N. L. P. SRIYANI \\ Fakultas Peternakan Universitas Udayana, Denpasar, Bali \\ e-mail: priskayani1234@gmail.com
}

\begin{abstract}
ABSTRAK
Daging sebagai sumber protein yang mudah rusak jika disimpan terlalu lama pada suhu ruang. Oleh karena itu perlu adanya alternatif seperti pengawetan ataupun pemberian rempah alami yang dapat menghambat kerusakan pada daging. Rempah yang biasa ditambahkan yaitu kencur (Kaempferia galangal L) yang dibuat menjadi blend. Penelitian ini bertujuan untuk mengetahui pengaruh rimpang kencur dan penyimpanan suhu dingin pada daging ayam petelur afkir. Penelitian dilakukan di Laboratorium Teknologi Hasil Ternak dan Mikrobiologi, Fakultas Peternakan Universitas Udayana, Kampus Sudirman selama 2 bulan. Penelitian menggunakan rancangan acak lengkap pola faktorial yang terdiri dari 2 faktor. Faktor I yakni konsentrasi o\% dan $5 \%$ dan faktor II yakni lama penyimpanan hari ke-o, ke-5 dan ke-10. Variabel yang diamati pada penelitian ini meliputi daya ikat air, $\mathrm{pH}$, susut masak dan total plant count. Hasil penelitian menunjukan marinasi dengan $5 \%$ blend kencur meningkatkan susut masak dan penurunan $\mathrm{pH}$ dan lama simpan 10 hari pada suhu dingin meningkatkan $\mathrm{pH}$ dan total plant count menurunkan daya ikat air dan susut masak. Terdapat interaksi antara marinasi blend kencur dan lama penyimpanan pada suhu dingin terhadap kualitas fisik dan total plant count daging ayam petelur afkir. Dari hasil penelitian ini dapat disimpulkan bahwa: (1) marinasi $5 \%$ blend kencur (meningkatkan susut masak dan penurunan $\mathrm{pH}$ ) dan lama simpan 10 hari pada suhu dingin (meningkatkan $\mathrm{pH}$ dan "total plate count"; menurunkan daya ikat air dan susut masak. (2) marinasi 5\% blend kencur dengan 5 hari penyimpanan pada suhu dingin, merupakan perlakuan terbaik ditinjau pada kualitas fisik (nilai pH 5,23; daya ikat air 65,03\%; susut masak 40,10\%) dan total mikroflora/total plate count 1,08 $\times 10^{-4} \mathrm{cfu} / \mathrm{g}$ daging ayam petelur afkir. (3) terdapat interaksi antara marinasi blend kencur dan penyimpanan pada suhu dingin terhadap kualitas fisik ( $\mathrm{pH}$, daya ikat air, susut masak) dan total mikroflora/total plate count daging ayam peterlur afkir.
\end{abstract}

Kata kunci: blend kencur, daging ayam petelur afkir, kualitas fisik, marinasi, total plate count

\section{THE EFFECT OF MARINATION OF KAEMPFERIS GALANGAL L AND COLD STORAGE TIME ON THE PHYSICAL QUALITY AND TOTAL PLATE COUNT OF AFKIR LAYER CHICKEN MEAT}

\begin{abstract}
Meat as a protein source is easily damaged if stored for too long at room temperature. The refore it is necessary to have alternatives such as preservation or natural spices that can inhibit damage to meat. The usual spice added is Kaempferia galangal $\mathrm{L}$ which is made into a blend. This study aims to determine the effect of Kaempferia galangal L rhizome and cold storage on rejected egg laying hens. This research was conducted at the Laboratory of Animal Products Technology and Microbiology, Faculty of Animal Husbandry, Udayana University, Sudirman Campus for 2 months. This study used completely randomized design with factorial pattern consisting of 2 factors. First factor is the concentration of $0 \%$ and $5 \%$ and second factor is the storage time of the $0^{\text {th }}, 5^{\text {th }}$ and $10^{\text {th }}$ days. The variables observed in this study included water binding capacity, $\mathrm{pH}$, cooking losses and total plant count. The results showed that marination with 5\% Kaempferia galangal L blend increased cooking shrinkage and decreased $\mathrm{pH}$ and shelf life of 10 days at cold temperatures increased $\mathrm{pH}$ and total plant count decreased water binding capacity and cooking losses. There is an interaction between Kaempferia galangal L blend marination and storage time at cold temperature on the physical quality and the total plant count of rejected laying hens. From the results of this study it can be concluded that: (1) marination of 5\% Kaempferia galangal L blend (increases cooking losses
\end{abstract}


and decreases $\mathrm{pH}$ ) and shelf life of 10 days at cold temperatures (increases $\mathrm{pH}$ and "total plate count"; reduced water binding capacity and cooking loss. (2) marination of 5\% Kaempferia galangal L blend with 5 days of storage at cold temperatures, is the best treatment in terms of physical quality ( $\mathrm{pH}$ value 5,23 ; water binding capacity 65,03\%; cooking loss 40,10\%) and total microflora / total plate count 1,08 x 10-4 cfu / g of egg laying hens rejected. (3) there is an interaction between marinated Kaempferia galangal L blend and cold storage on physical quality ( $\mathrm{pH}$, water holding capacity, cooking losses) and total microflora / total plate count of chicken peterlur afkir

Keywords: Kaempferia galangal L blend, culled laying chicken, physical quality, marinaton, total plate count

\section{PENDAHULUAN}

Daging merupakan salah satu sumber protein hewani tang baik untuk mensuplai kebutuhan gizi masyarakat. Dari segi gizi, komposisi protein hewani lebih lengkap dibandingkan protein nabati. Menurut Lawrie (2003), nilai nutrisi daging yang tinggi disebabkan karena daging mengandung asam-asam amino yang lengkap dan seimbang. Pada umumnya ketersediaan daging dipasar dalam bentuk segar. Pemanfaatan daging ayam petelur afkir yang sudah tidak berproduksi sebagai ayam potong yang bertujuan untuk memanfaatkan hasil sisa produksi dan sebagai alternatif sumber daging karena potensi nilai gizinya yang cukup tinggi. Kurniawan (2011) melaporkan daging ayam petelur afkir mengandung protein $25,4 \%$, air $56 \%$ dan lemak 3\%$7,3 \%$. Jika dibandingkan dengan daging ayam broiler menurut Miwada (2015), daging broiler memiliki kadar air daging yang tinggi (68-75\%) dan kaya akan zat yang mengandung nitrogen.

Daging merupakan salah satu bahan pangan yang mudah rusak oleh mikroba jika tidak dilakukan suatu upaya pengawetan. (Okarini et al., 2013) penanganan daging segar setelah post-mortem pada kondisi oksigen tidak terbatas, daging mudah mengalami perubahan fisikokimia yang dapat menurunkan kualitas daging. Menurut Setyawan et al., (2017) tingkat cemaran mikroba pada daging ayam yang di pasarkan di pasar tradisional (Sanglah, Kreneng dan Pemedilan) untuk “Total Plate Count" berkisaran 4,52 x 107-2,77 x $10^{8}$ $\mathrm{cfu} / \mathrm{g}$. beberapa penelitian yang dilakukan untuk memperlambah pertumbuhan bakteri seperti yang dilakukan Afrianti et al. (2013) yang menyatakan bahwa pengawetan daging ayam dengan direndam ekstrak daun senduduk pada suhu ruang dengan kosentrasi15\% dapat memberikan perubahan profil protin dan mutu organolektif daging ayam. Menurut Kusumaningrum et al. (2010) yang menyatakan bahwa daging ayam yang direndam dengan daun salam dengan kosentrasi 10\% dapat menurunkan jumlah bakteri Salmonella sp.

Untuk mencengah perubahan fisikokimia yang tidak diinginkan maka perlu dilakukan pencegahan atau pengolahan salah satu cara yang dapat digunakan yaitu pengawetan dengan menerapkan marinasi untuk menghambat pertumbuhan mikroba pembusuk dan memperpanjang masa simpan daging. Marinasi adalah proses perendaman daging dalam bahan marinade. Marinade adalah larutan berbumbu yang berfungsi sebagai perendam daging, biasanya untuk meningkatkan cita rasa, kesan jus dan keempukan daging setelah dimasak (Brooks, 2011). Dengan demikian marinasi daging dapat dimanfaatkan untuk memperbaiki sifat fisik daging dan sebagai bahan pengawet untuk memperpanjang masa simpan (Nurwantoro et al., 2012), meningkatkan citarasa, keempukan dan penerimaan konsumen (Birk et al., 2010).

Salah satu bahan alami yang dapat digunakan sebagai bahan pengawet alami adalah kencur (Kaempferia galangal $L$ ) dimana kencur mengandung minyak atsiri yang berfungsi sebagai antimikroba alami. Minyak atsiri akhir-akhir ini menarik perhatian dunia, usaha pencarian senyawa baru terhadap tumbuhan juga semakin banyak, hal ini disebabkan minyak atsiri dari beberapa tumbuhan bersifat aktif biologis sebagai antibakteri dan anti jamur sehingga dapat dipergunakan sebagai bahan pengawet pada makanan dan sebagai antibiotik alami. Selain dengan cara penambahan bahan pengawet alami, pengawetan dengan cara menyimpanan pada suhu dingin (lemari es) juga dapat dilakukan. Aryres et al. (1980), menyatakan bahwa daging ayam yang disimpan pada suhu $5^{\circ} \mathrm{C}$ mempunyai daya tahan selama 14-16 hari dan pada suhu $10^{\circ}$ bau dan lendir terjadi setelah 3 hari daging di simpan. Sedangkan Buckle et al. (1987) menyatakan bahwa mikroorganisme psikrofilik mempunyai kemampuan untuk tumbuh pada suhu lemari es. Terutama $\mathrm{O}^{\mathrm{O}}-5^{\mathrm{O}} \mathrm{C}$ dan memungkinkan terjadinya kerusakan daging oleh mikroba, sehingga untuk memperpanjang masa simpan perlu dilakukan kombinasi perlakuan yaitu disamping dengan cara pendinginan juga dapat ditambahkan bahan pengawet (Ferdiaz,1989).

Tujuan dari penelitian ini mengetahui interaksi antara marinasi "blend" kencur dan lama penyimpanan pada suhu dingin terhadap kualitas fisik dan "total plate count" daging ayam petelur afkir dan untuk mengetahui ada tidaknya interaksi antara marinasi "blend" kencur dan lama penyimpanan pada suhu dingin terhadap kualitas fisik dan "total plate count" daging. Terbatasnya 
publikasi hasil penelitian marinasi blend kencur pada fillet daging ayam petelur afkir terhadap kualitas fisik dan total mikroflora atau total plate count daging, maka dilakukan penelitian ini.

\section{MATERI DAN METODE}

Materi dari penelitian terdiri atas: (1) Daging ayam yang digunakan dalam penelitian ini adalah daging ayam petelur afkir, recahan bagian dada "Musculus Pectoralis Superficialis" sebanyak $4 \mathrm{~kg}$, dibeli dari rumah potong unggas. Daging dibungkus dengan plastik semi-steril dan dimasukkan ke dalam termos plastik yang berisi es kering "dry ice", kemudian dibawa ke laboratorium (tempat penelitian), (2) Bahan-bahan yang digunakan adalah rimpang kencur segar, daging ayam petelur afkir, recahan bagian dada sebanyak $4 \mathrm{~kg}$, aquades, alkohol $70 \%$ dan larutan pepton $(\mathrm{NaCl} 0,9 \%)$ dan media "Nutrient Agar" atau "Plate Count Agar", (3) Peralatan yang digunakan dalam penelitian ini antara lain: pisau, talenan, wadah plastik, besi pemberat, kaca plat, kertas saring, timbangan analitik, kertas label, mixer/blender, $\mathrm{pH}$ meter, nampan, kompor, panci, tabung reaksi, inkubator, cawan petri, pemanas bunsen, almari pendingin, gelas ukur, pipet volume $1 \mathrm{ml}$.

Metode penelitian yang digunakan yaitu: (1) Penelitian ini dilakukan di laboratorium THT (Teknologi Hasil Ternak) dan Mikrobiologi Fakultas Peternakan, Universitas Udayana, Kampus Sudirman Denpasar. (2) Rancangan percobaan yang digunakan rancangan acak lengkap (RAL) pola faktorial: faktor 1 yaitu perlakuan konsentrasi "blend" kencur (o\%, dan 5\%) dan faktor 2 yaitu lama penyimpanan pada suhu dingin (hari ke-o, hari ke-5, dan hari ke-10), tiap kombinasi perlakuan diulang 3 kali. Sehingga penelitian menggunakan $2 \times 3 \times 3=18$ unit percobaan, (3) Persiapan "blend" kencur: memilih rimpang kencur segar, mengupas kulitnya dan mencuci dengan aquades hingga bersih, memotong kecil-kecil kencur, m enghaluskan kencur dengan blender, tanpa penambahan air. Menentukan konsentrasi blend kencur dengan cara: $5 \%$ blend kencur (5 g kencur yang telah diblender dan ditambahkan aquades hingga volume larutan mencapai $100 \mathrm{ml}$, ekstrak kencur konsentrasi 5\% per berat basah), (4) Daging ayam dipotong-potong berbentuk sebanyak 18 potongan, masing-masing dengan berat $40 \mathrm{~g}$. Kemudian semua sampel dicelupkan ke dalam larutan garam fisiologis (sebelum diberi perlakuan) untuk menyeragamkan jumlah cemaran mikroba selama 5 menit. Daging dibagi menjadi dua kelompok sesuai dengan perlakuan, dengan pinset daging diambil untuk dilakukan perendaman dalam blend kencur dengan konsentrasi $0 \%$ dan $5 \%$ selama 30 menit. Kemudian ditiriskan dan daging dimasukkan ke dalam kantong plastik steril lalu di segel. Selanjutnya daging disimpan pada suhu dingin dan pengamatan dilakukan pada penyimpanan o hari, 5 hari dan 10 hari.

\section{Variabel yang diamati dalam penelitian adalah:}

1. daya ikat air: Pengukuran daya ikat air dapat dilakukan dengan menggunakan metode pemusingan (metode sentrifius dimodifikasi). Daging sebanyak $10 \mathrm{~g}$ ditimbang untuk mengetahui berat awalnya, kemudian sampel dilumatkan dan selanjutnya dibungkus dengan kertas sarinng. Pemusingan dilakukan dengan selama 30 menit. Daging yang telah dipusingkan ditimbang kembali. DIA dapat di tentukan dengan rumus (Arka et al., 1992)

DIA $=\frac{\text { Berat setelah dipusingkan }}{\text { Berat awal }} \times 100 \%$

2. Analisis $\mathrm{pH}$ daging ayam ditentukan berdasarkan analisis kimia menurut SNI (1992); (1) daging yang telah diberikan perlakuan kontrol dan $5 \%$ blend kencur dihaluskan dan ditambahkan aquades $10 \mathrm{ml}$, (2) kemudian dituangkan ke dalam gelas piala $100 \mathrm{ml}$, (3) elektroda dicelupkan ke dalam gelas piala yang telah diberisi daging ayam, pembacaan $\mathrm{pH}$ dilakukan apabila skala $\mathrm{pH}$ meter sudah stabil

3. Langkah uji susut masak dapat dilakukan dengan cara : Menyiapkan sampel daging, menimbang sampel dengan berat \pm 20 gram sebagai berat awal memasukkan kedalam kantong plastik (untuk direbus), memasak pada suhu $100^{\circ} \mathrm{C}$ selama 30 menit, mendinginkan sampel pada suhu ruang dan menimbang kembali dan menghitung susut masak dengann rumus:

$$
S M=\frac{\text { Berat awal }- \text { Berat akhir }}{\text { Berat awal }} \times 100 \%
$$

4. Langkah uji TPC yaitu: Menghaluskan sampel (daging ayam), menimbang sampel sebanyak $5 \mathrm{~g}$. Menurut Waluyo (2005), tahapan pengenceran dimulai dari membuat larutan sampel sebanyak $10 \mathrm{ml}$ (campuran $1 \mathrm{ml} / 1 \mathrm{~g}$ sampel $9 \mathrm{ml}$ larutan pepton). Dari larutan tersebut diambil $1 \mathrm{ml}$ dan masukkan ke dalam tabung reaksi berikutnya sehingga di dapatkan pengenceran $10^{-2}$, begitu seterusnya sampai mencapai pengenceran yang diinginkan. Selanjutnya mengambil larutan dari 2 tabung reaksiterakhir $\left(10^{-6}\right.$ dan $\left.10^{-7}\right)$ menuangkan pada cawan petri selanjutnya ditambahkan media berupa agar, dan putar seperti angka 8 agar sampel dan media tercampur rata dan memadat dan kemudian cawan diinkubasi pada suhu $37^{\circ} \mathrm{C}$ selama 2 x 24 jam. 
Semua data pengamatan $\mathrm{pH}$, susut masak, daya ikat air dan total plate counts daging yang diperoleh, terlebih dahulu ditransformasi ke log Y selanjutnya dianalisis dengan sidik ragam, apabila terdapat perbedaan yang nyata $(\mathrm{P}<0,05)$ diantara perlakuan maka analisis diajukan dengan Uji Jarak Berganda Duncan (Stell dan Torrie, 1980) dan untuk data TPC selanjutnya di transformasi anti log untuk mengembalikan ke data asli.

\section{HASIL DAN PEMBAHASAN}

\section{Nilai pH}

Tabel 1. Rataan nilai pH daging ayam petelur afkir yang dimarinasi blend kencur dan lama penyimpanan pada suhu dingin

\begin{tabular}{cccc}
\hline \multirow{2}{*}{$\begin{array}{c}\text { Lama Penyim- } \\
\text { panan (Hari) }\end{array}$} & \multicolumn{2}{c}{ Kosentrasi Blend Kencur (\%) } & Rataan \\
\cline { 2 - 3 } K0 & K5 & \\
\hline W0 & $4,71^{\mathrm{a}}$ & $4,60^{\mathrm{a}}$ & $4,66^{\mathrm{a}}$ \\
W5 & $5,10^{\mathrm{b}}$ & $5,23^{\mathrm{bc}}$ & $5,16^{\mathrm{b}}$ \\
W10 & $5,20^{\mathrm{bc}}$ & $5,32^{\mathrm{a}}$ & $5,26^{\mathrm{b}}$ \\
\hline Rataan & $5,00^{\mathrm{a}}$ & $5,05^{\mathrm{a}}$ & \\
\hline
\end{tabular}

Keterangan:

Nilai dengan huruf yang berbeda pada baris yang sama menunjukan perbedaan yang nyata $(P<0,05)$

KOWO $=$ kosentrasi $0 \%$ waktu 0 hari

K5W0 = kosentrasi $5 \%$ waktu 0 hari

KOW5 = kosentrasi $0 \%$ waktu 5 hari

- K5W5 = kosentrasi 5\% waktu 5 hari

KOW10 $=$ kosentrasi $0 \%$ waktu 10 hari

$\mathrm{K} 5 \mathrm{~W} 10=$ kosentrasi $5 \%$ waktu 10 hari

Lama penyimpanan tidak berpengaruh nyata terhadap $\mathrm{pH}$. Interaksi kedua perlakuan berpengaruh nyata terhadap daya ikat air, susut masak dan total plant count pada perlakuan konsentrassi dan lama penyimpanan serta interaksi antara kedua perlakuan dapat dilihat pada Tabel (1). Nilai pH daging merupakan salah satu faktor penting dalam menentukan kualitas daging. Hasil penelitian pada tabel menunjukan terjadi interaksi (WoKo dan WoK5) antara kedua perlakuan pada daging ayam yang diberikan perlakuan kontrol dan penambahan blend kencur 5\% dengan waktu simpan hari ke-o sampai hari ke-10 mengalami peningkatan dimana $\mathrm{pH}$ yang dihasilkan masih rendah (asam) pada perlakuan kontrol dan penambahan $5 \%$ blend kencur daging ayam yang disimpan selama 0-10 hari pada suhu dingin tidak mengalami pembusukan. Karena nilai $\mathrm{pH}$ normal daging ayam berkisaran antara 5,96 sampai 6,107 (Van Laak et al., 2000). Adanya perbedaan $\mathrm{pH}$ antara perlakuan disebabkan oleh kadar glikogen dalam jaringan otot, yang berimbas pada penimbunan asam laktat dalam daging. Peningkatan $\mathrm{pH}$ biasanya disebabkan lebih terbukanya struktur filamin miofibrilar sehingga menyebabkan semakin banyak air yang masuk dalam hal ini mendukung pula peningkatan WHC (water holding capacity).

Selama penyimpanan suhu dingin sampai hari ke-10 diperoleh peningkatan secara nyata pada $\mathrm{pH}$ daging $(\mathrm{P}<0.05)$. Peningkatan $\mathrm{pH}$ ini terjadi akibat proses dekomposisi protein oleh enzim proteolitik dan tunjangan oleh aktivitas mikroba (Buckle et al., 1987). Daging dengan $\mathrm{pH}$ yang rendah (asam) penting bagi pengawetan karena dapat menghambat pertumbuhan mikroba selain itu pada kecur mengandung zat antimikroba. Arizona et al. (2011) menyatakan bahwa nilai $\mathrm{pH}$ daging yang semakin tinggi karena bakteri mendeaminasi asam amino sehingga menghasilkan senyawa-senyawa yang bersifat basa hal tersebut yang menyebabkan kenaikan $\mathrm{pH}$.

\section{Daya Ikat Air}

Tabel 2. Rataan nilai daya ikat air (\%) daging ayam petelur afkir yang dimarinasi dengan blend kencur dan lama penyimpanan pada suhu dingin

\begin{tabular}{cccc}
\hline \multirow{2}{*}{$\begin{array}{c}\text { Lama Penyim- } \\
\text { panan (Hari) }\end{array}$} & \multicolumn{2}{c}{ Kosentrasi Blend Kencur (\%) } & \multirow{2}{*}{ Rataan } \\
\cline { 2 - 3 } W0 & $71,53^{\mathrm{b}}$ & $71,02^{\mathrm{b}}$ & $71,27^{\mathrm{b}}$ \\
W5 & $62,69^{\mathrm{ab}}$ & $65,03^{\mathrm{ab}}$ & $63,86^{\mathrm{ab}}$ \\
W10 & $69,65^{\mathrm{b}}$ & $59,24^{\mathrm{a}}$ & $64,44^{\mathrm{ab}}$ \\
\hline Rataan & $67,95^{\mathrm{a}}$ & $65,09^{\mathrm{b}}$ & \\
\hline Keterangan: & & \\
- Nilai dengan huruf yang berbeda pada baris yang sama menunjukan perbedaan yang \\
nyata (P<0,05) & & \\
- K0W0 = kosentrasi 0\% waktu 0 hari & & \\
- K5W0 = kosentrasi 5\% waktu 0 hari & & \\
- K0W5 = kosentrasi 0\% waktu 5 hari & & \\
- K5W5 = kosentrasi 5\% waktu 5 hari & & \\
- K0W10 = kosentrasi 0\% waktu 10 hari & & \\
- K5W10 & kosentrasi 5\% waktu 10 hari
\end{tabular}

Daya ikat air (DIA) merupakan parameter kualitas daging yang sangat terkait dengan dengan kemampuan air. Daya ikat air juga menunjukan seberapa besar kemampuan daging untuk mengikat air dalam bentuk persen. Hasil penelitian menunjukan bahwa persentase daya ikat air daging ayam petelur afkir (Tabel 2) menunjukan terjadinya interaksi. Daya ikat air pada perlakuan $5 \%$ blend kencur mengalami penurunan dari hari ke-o sampai hari ke-10. Sedangkan pada perlakuan kontrol penurunan pada terjadi pada hari ke-o sampai ke-5. Hasil ini menunjukan terjadi penurunan prosentase daya ikat air pada daging ayam yang diberikan perlakuan dengan kosentrasi $5 \%$ hal ini terjadi karena tingginya konsentrasi blend kencur yang di berikan. Tingginya kosentrasi yang diberikan menyebabkan ion hidrogen yang masuk ke dalam daging akan semakin banyak sehingga $\mathrm{pH}$ daging akan semakin rendah (Fennema, 1976). Sedangkan menurut Forrest et al (2003) berkurangnya daya ikat air daging tergantung pada banyaknya gugus reaktif protein, banyaknya asam laktat menyebabkan keadaan $\mathrm{pH}$ menurun. Hal ini juga sesuai dengan pendapat (Bouton et al.,1971; Wismer dan Pedesen, 1971 yang dikutip oleh Soeparno, 1992) bahwa daya ikat air berhubungan erat dengan $\mathrm{pH}$. Lebih lanjut dikatakan bahwa penurunan 
pH akan menyebabkan terjadinya pengerutan miofibrin daging dan protein akan kehilangan kemampuan untuk mengikat cairan, serta struktur daging longgar dengan demikian daya ikat air protein daging menjadi rendah.

Pengaruh jangka waktu penyimpanan pada suhu dingin terhadap daya ikat air pada daging ayam baik daging dengan perlakuan kontrol maupun dengan pemberian $5 \%$ blend kencur menunjukan rata-rata prosentase daya ikat air daging yang disimpan pada suhu dingin dengan waktu penyimpanan hari ke-o, ke-5 dan ke-10 mengalami penurunan, seiring dengan penurunan $\mathrm{pH}$ akibat lama penyimpanan, maka daya ikat air menurun. Begitu pula yang terjadi pada ke 2 perlakuan dengan lama penyimpanan hari ke-o sampai hari ke-10. Hal ini sesuai dengan pendapat Soeparno (2009) yang menyatakan adanya perbedaan daya ikat air sebagian juga disebabkan oleh laju dan besarnya penurunan $\mathrm{pH}$. Hal ini juga diperkuat oleh pernyataan Bahar (2003) yang menyatakan bahwa daya ikat air dipengaruhi oleh laju dan besarnya nilai $\mathrm{pH}$. Semakin lama penyimpanan maka nilai daya ikat airnya semakin rendah.

\section{Susut Masak}

Tabel 3. Nilai Rataan susut masak (\%) daging ayam petelur afkir yang dimarinasi dengan blend kencur dan lama penyimpanan pada suhu dingin

\begin{tabular}{cccc}
\hline \multirow{2}{*}{$\begin{array}{c}\text { Lama Penyim- } \\
\text { panan (Hari) }\end{array}$} & \multicolumn{2}{c}{ Konsentrasi Blend Kencur (\%) } & \multirow{2}{*}{ Rataan } \\
\cline { 2 - 3 } K0 & K5 & \\
\hline W0 & $41,41^{\mathrm{a}}$ & $47,92^{\mathrm{b}}$ & $44,66^{\mathrm{b}}$ \\
W10 & $40,86^{\mathrm{a}}$ & $40,10^{\mathrm{a}}$ & $40,48^{\mathrm{a}}$ \\
W10 & $47,53^{\mathrm{b}}$ & $46,89^{\mathrm{b}}$ & $47,21^{\mathrm{b}}$ \\
\hline Rataan & $43,26^{\mathrm{a}}$ & $44,96^{\mathrm{b}}$ & \\
\hline
\end{tabular}

Keterangan:

- Nilai dengan huruf yang berbeda pada baris yang sama menunjukan perbedaan yang nyata $(P<0,05)$

- KOWO =kosentrasi $0 \%$ waktu 0 hari

- K5W0 = kosentrasi $5 \%$ waktu 0 hari

- KOW5 = kosentrasi $0 \%$ waktu 5 hari

K5W5 = kosentrasi $5 \%$ waktu 5 hari

- KOW10 = kosentrasi $0 \%$ waktu 10 hari

- K5W10 = kosentrasi $5 \%$ waktu 10 hari

Susut masak diartikan sebagai persentase berat yang hilang dibandingkan sebelum pemasakan. Atau dapat dikatakan penurunan bobot selama pemasakan. Soeparno (1994) menyatakan bahwa susut masak merupakan indikator terhadap nilai nutrisi daging dan berhubungan dengan banyaknya jumlah air terikat di dalam sel antara serabut otot. Susut masak daging dipengaruhi oleh temepratur dan lama pemasakan. Semakin tinggi temperatur pemasakan maka semakin besar cairan daging yang hilang. Besarnya susut masak dipengaruhi banyaknya kerusakan membran seluler, banyaknya air yang keluardari daging, umur simpan daging, degradasi daging dan kemampuan daging untuk mengikat air (Shanks et al., 2007).

Hasil penelitian yang diilakukan terhadap besarnya persentase nilai rataan susut masak daging ayam petelur afkir (Tabel 3) menunjukan susut masak pada daging dengan perlakuan kontrol dan $5 \%$ blend kencur pada hari ke-o sampai hari ke-5 mengalami penurunan, sedangkan susut masak pada hari ke-o sampai hari ke10 memberikan pengaruh nyata $(\mathrm{P}<0.05)$. Perbedaan yang tidak nyata pada lama penyimpanan hari ke- 5 disebabkan oleh protein miofibrin belum terdegradasi, sehingga kemampuan daging untuk mengikat air masih baik selain itu susut masak juga dapat dipengaruhi oleh nilai $\mathrm{pH}$, panjang sarkomer serabut otot, panjang potongan serabut otot, ukuran dan berat sampel. Susut masak meningkat karena kadar air yang dihasilkan rendah sehingga kemampuan daging mengikat air rendah yang menyebabkan banyaknya air yang menyusut. Hasil penelitian ini didukung oleh Roham et al. (2015) yang menyatakan bahwa lama marinasi dalam ekstrak nanas, juga berpengaruh nyata terhadap susut masak daging ayam petelur afkir. Hal ini sesuai dengan pendapat Abustam dan Ali (2010) dalam Endah Purnamasari (2013) jika kadar air rendah maka susut masak menurun. Didukung pula oleh Soeparno (2005) menyatakan bahwa daging dalam jumlah susut masak rendah mempunyai kualitas yang lebih baik karena kehilangan nutrisi saat pemasakan akan lebih rendah. Soeparno (2005) menyatakan bahwa $80^{\circ} \mathrm{C}$ adalah temepratur yang ideal untuk perlakuan thermal (panas) karena sampel daging menjadi cukup tepat kekerasannya untuk dipotong-potong menjadi sub sampel pengujian kualitas. Astika et al. (2017) menyatakan susut masak pada daging ayam broiler yang dibeli di beberapa pasar kota Denpasar memiliki susut masak yang masih normal $(25,26 \%$ - 25,82\%). Begitu juga dengan penelitian ini mendapatkan susut masak yang masih tergolong normal. Sesuai dengan pernyataan Soeparno (2005) bahwa susut masak daging bervariasi mulai dari 15\% hingga $54,5 \%$.

\section{Total Plate Count}

Tabel 4. Nilai rataan total plate count (CFU/ml) daging ayam petelur afkir yang dimarinasi dengan blend kencur dan lama penyimpanan pada suhu dingin.

\begin{tabular}{cccc}
\hline \multirow{2}{*}{$\begin{array}{c}\text { Lama Penyimpa- } \\
\text { nan (Hari) }\end{array}$} & \multicolumn{2}{c}{ Kosentrasi Blend Kencur (\%) } & \multirow{2}{*}{ Rata-rata } \\
\cline { 2 - 3 } K0 & $1,10 \times 10^{-4 a b}$ & $1,09 \times 10^{-4 a b}$ & $1,10 \times 10^{-4 a b}$ \\
W5 & $1,03 \times 10^{-4 a}$ & $1,08 \times 10^{-4 a b}$ & $1,06 \times 10^{-4 a b}$ \\
W10 & $1,10 \times 10^{-5 b}$ & $1,36 \times 10^{-5 c}$ & $1,23 \times 10^{-5 c}$ \\
\hline Rata-rata & $1,17 \times 10^{-4 a b}$ & $1,03 \times 10^{-5 b}$ & \\
\hline
\end{tabular}

Keterangan:

- Nilai dengan huruf yang berbeda pada baris yang sama menunjukan perbedaan yang nyata $(P<0,05)$

KOWO =kosentrasi $0 \%$ waktu 0 hari

- K5W0 = kosentrasi $5 \%$ waktu 0 hari

KOW5 $=$ kosentrasi $0 \%$ waktu 5 hari

K5W5 = kosentrasi $5 \%$ waktu 5 hari

KOW10 $=$ kosentrasi $0 \%$ waktu 10 hari

$\mathrm{K} 5 \mathrm{~W} 10=$ kosentrasi $5 \%$ waktu 10 hari 
Pada Tabel 4 jumlah bakteri pada perlakuan kontrol dan 5\% blend kencur pada hari ke-o sampai dengan hari ke-5 mengalami penurunan. Sedangkan pada masa simpan hari ke-1o baik pada daging dengan perlakuan kontrol maupun dengan konsentrasi blend kencur mengalami peningkatan. Pada Tabel 4 menunjukan adanya interaksi antara perlakuan dan lama penyimpanan. Kencur memiliki kandungan minyak atsiri yang tinggi dan berfungsi sebagai zat antimikroba di dalamnya yang berfungsi menghambat pertumbuhan mikroba. Namun pada penelitian ini daging yang diberikan perlakuan dengan $5 \%$ blend kencur mengalami peningkatan jumlah bakteri. Hal ini dapat terjadi karena daging sudah dari awal memiliki beban bakteri yang melebihi persyaratan. Keadaan ini menunjukan sampel sudah tercemar $E$. coli. Cemaran ini dapat berasal dari peralatan yang digunakan, proses pemotongan, air yang digunakan untuk mencuci.

Hasil penelitian ini memperlihatkan bahwa semakin lama penyimpanan akan diikuti oleh peningkatan jumlah bakteri. Stainer et al. (1977) menyatakan bakteri-bakteri akan membutuhkan waktu yang cukup untuk tumbuh dan berkembangbiak. Apabila komponen yang diperlukan cukup tersedia, maka bakteri akan berkembang dengan pesat. Waktu untuk pembelahan sel bakteri adalah 10-60 menit pada tempratur optimal pertumbuhannya (Buckle et al.,1987). Suhu adalah salah satu faktor pendukung sangat penting untuk pertumbuhan bakteri. Pengaruh suhu terhadap pertumbuhan bakteri disebabkan karena suhu meempengaruhi aktivitas enzim yang mengkatalis reaksi biokimia (Fardiaz, 1993). Menurut Frazier dan Westhoff, 1983 dalam Tjondrodiharjo (1992), bahwa jumlah kosentrasi dan waktu kontak merupakan bagian dari faktor yang mempengaruhi efektivitas antimikroba. Setyawan (2017) menyatakan daging ayam yang di beli dipasar Sanglah menunjukan hasil TPC yang diperoleh yaitu sebesar $2.77 \times 10^{-8} \mathrm{cfu} / \mathrm{g}$.

\section{SIMPULAN}

Dari hasil penelitian ini dapat disimpulkan bahwa:1. marinasi $5 \%$ blend kencur (meningkatkan susut masak dan penurunan $\mathrm{pH}$ ) dan lama simpan 10 hari pada suhu dingin (meningkatkan $\mathrm{pH}$ dan total plate count; menurunkan daya ikat air dan susut masak). 2. marinasi $5 \%$ blend kencur dengan 5 hari penyimpanan pada suhu dingin, merupakan perlakuan terbaik ditinjau pada kualitas fisik (nilai pH 5,23; daya ikat air 65,03\%; susut masak 40,10\%) dan total mikroflora/total plate count $1.08 \times 10^{-4} \mathrm{cfu} / \mathrm{g}$ daging ayam petelur afkir. 3 . terdapat interaksi antara marinasi blend kencur dan penyimpanan pada suhu dingin terhadap kualitas fisik (pH, daya ikat air, susut masak) dan total mikroflora/ total plate count daging ayam petelur afkir.

\section{DAFTAR PUSTAKA}

Afrianti M, Dwiloka B, Setiani BE. 2013. Total bakter, pH, dan kadar air daging ayam broiler setelah direndam dengan ekstrak daun senduduk (Melastoma malabathricum L) selama masa simpan. Jurnal Pangan Dan Gizi 4 (7): 49-59.

Arka, I.B., Bagiasih, W., Swacita, I.B., Suada. K., Maergawani, K.R. 1992. Ilmu kesehatan Masyarakat Veteriner II./Teknologi Daging. Program Studi Kedokteran Hewan. Universitas Udayana. h. 12-13.

Arizona, R., E Suryanto, dan Y. Eewanto. 2011. Pengaruh Kosentrasi Asap Cair Tempurung Kenari dan Lama Penyimpanan Terhaddap Kualitas Kimia dan Fisik Daging. Buletin Peternakan.35 (1): 50-56.

Astika, I N.S. Miwada dan S. A. Lindawati. 2017. Studi Daging Ayam Fisik Ayam Yang Dijual Di Beberapa Pasar Di Denpasar. Jurnal Peternakan Tropika. 5(2) : 299-310.

Ayres, J.C., Mundt, J.O., Sandine, W.E1980. Mikrobiology pf Foods. W.H Freemand and Company. Sanfransico. Pp. 481, 488.

Birk, T., A.C. Gronlund, B.B Christensen, S. Knochel, K. Lohse and H. Rosenquist.2010. Effect of organic acids and margination ingredients on the survival of Campylobacter jejuni on meat. J. Food Protect. 73(2): 258-265.

Brooks, C. 2011. Marinating of Beef for Enhancement.

Buckle, K.A., Edward, R.A., Fleet, G.H., Wooton, M., 1987. Ilmu Pangan. Terjemahan Hari Purnomo dan Adiono. UI. Press Jakarta.

Bahar, B, 2003. Panduan Praktis Memilih Produk Daging Sapi. Penerbit Gramedia Pustaka Utama Jakarta.

Fardiaz, S. 1989. Analisis Mikrobiologi Pangan, Dapertemen Pendidikan Tinggi, Pusat Antar Universitas Pangan dan Gizi. Institut Pertanian Bogor.

Forrest, J.C., Arbele, F.I.D., H.B. Hendric, I.D. Judal. Ra. Markel. 1975. Principle of Meat Science, First ed. W.H. Freemand and Co., San Francisco.

Kusumaningrum. A., P. Widiyaningrum., I. Mubarok. 2013. Penurunan Total Bakteri Daging Ayam Dengan Perlakuan Perendaman Infusa Daun Salam (Syzygium Polyanthum). Junal of Biology and Biology Education 36 (1):14-19.

Larwi, R. A. 2003. Ilmu Daging. Parakkasi A: penerjemah. UI Press. Jakarta. Terjemahan dari: Meat Science.

Miwada, I N. S. 2015. Teknologi Pembekuan Daging: Bentuk Selamat Dari Pembusukan. Karya Ilmiah, Fakultas Peternakan Universitas Udayana, Denpasar.

Nurwantoro, Nurohim dan D. Sunaarti. 2013. Pengaruh metode marinasi dengan bawang putih pada daging itik terhadap pH, daya ikat airdan total coliform. J. 
Animal Agric. 1(20:77-85.

Okarini, I. A., Hari Purnomo, Aulanni a m and L.E. Radiati. 2013. Proximate, toral phenolic, antioxidant activity and amino acids profile of bali indigenous chiken, spent laying hen broiler breast fillet. International Journal of Poultry Science. 12 (7): 41-420, 2013.

Rohman, F., R. Eny M., dan H. D Arifin. 2015. Pengaruh dosis dan lama perendaman ekstrak nanas (Ananas comosus $L$. merr) terhadap kualitas fisik daging dada ayam petelur afkir. Jurnal Surya Agritama 4 (1): 35-42.

Setyawan, S.A. Lindawati, dan I N.S. Miwada. 2017. Menilai Gelombang Penyebaran Microba Pada Daging Ayam yang Dijual Di Beberapa Pasar Tradisional DI Denpasar. Jurnal Peternakan Tropika. V. 5, n. 2, hal 311-323.

Soeparno. 2009. Ilmu dan Teknologi Daging. Edisi ke-6. Gadjah Mada University Press. Yogyakarta.

Soeparnao. 2005. Ilmu dan Teknologi Daging. Cetakan ke-5. Gadjah Mada University Press. Yogyakarta.

Soeparno. 1994. Ilmu dan Teknologi Daging. Fakultas Peternakan Universitas Gadjah Mada, Gadjah Mada Universuty Press.

Tjondrodoharjo, A.H., 1992. Aktifitas Antimikroba Bumbu Gulai Terhadap Pertumbuhan Beberapa Bakteri Patogen. Fakultas Pertanian. IPB Bogor. h. 30-34.

Waluyo. 2005. Mikrobiologi Umum. Erlangga: Jakarta 